\title{
Andes imaginarios. El mundo precolombino y Oriente en algunos ensayos del indianismo argentino
}

Imaginary Andes The Pre-Columbian world and the Orient in some essays of the Argentinian Indianism

\section{Alejandra Mailhe}

\section{OpenEdition}

\section{Journals}

\section{Electronic version}

URL: https://journals.openedition.org/corpusarchivos/4449

DOI: 10.4000/corpusarchivos.4449

ISSN: 1853-8037

\section{Publisher}

Diego Escolar

\section{Electronic reference}

Alejandra Mailhe, «Andes imaginarios. El mundo precolombino y Oriente en alqunos ensayos del

indianismo argentino», Corpus [En línea], Vol. 11, №. 1 | 2021, Publicado el 15 junio 2021, consultado el 03 julio 2021. URL: http://journals.openedition.org/corpusarchivos/4449 ; DOI: https://doi.org/

10.4000/corpusarchivos.4449

This text was automatically generated on 3 July 2021.

Licencia Creative Commons: Atribución-NoComercial 2.5 Argentina (CC BY-NC 2.5 AR) 


\section{Andes imaginarios. El mundo precolombino y Oriente en algunos ensayos del indianismo argentino}

Imaginary Andes The Pre-Columbian world and the Orient in some essays of the Argentinian Indianism

Alejandra Mailhe

\section{EDITOR'S NOTE}

Fecha de recepción del original: 26/10/2020

Fecha de aceptación para publicación: 12/05/2021

1 ¿Por qué vías el pensamiento argentino de entre siglos legitima el legado indígena? ¿Mediante qué argumentos se habilita un retorno al mundo precolombino como posible origen de la nación, en un contexto como el argentino, que tiende a negar históricamente el legado indígena? ¿Qué beneficios simbólicos supone, por entonces, afirmar el origen "indoeuropeo" de las civilizaciones prehispánicas? ¿Y qué resistencias y proyecciones suscita esa matriz discursiva en las décadas siguientes...?

2 Este trabajo explora estos interrogantes a partir del análisis del ensayo El oculto entre los aborígenes de América del Sur (1901) de Henri Girgois, marcado por un relativismo cultural notable y atípico para la época, y muy poco considerado hasta el presente por la crítica. Para interpretar mejor esta fuente, parte de considerar brevemente un texto previo, Les races aryennes du Pérou (1871) de Vicente Fidel López, que incide fuertemente en la perspectiva de Girgois. En última instancia, busca iluminar las bases esotéricas del indianismo argentino posterior, de autores importantes en los años veinte y treinta como Ricardo Rojas, y contrastar estas perspectivas espiritualistas con la desautorización de ese tipo de especulaciones "fabulosas" por parte de la antropología científica, encarnada por figuras como José Imbelloni. 


\section{Genealogías de alcurnia}

3 La ruptura política y cultural desencadenada por las guerras de Independencia, a principios del siglo XIX, deja a los letrados románticos frente a una suerte de "callejón sin salida", ante las dificultades para idealizar culturas populares de matriz indígena (o peor aún, africana) que contradicen los parámetros de la jerarquía eurocéntrica. Esa situación se exaspera en contextos como el argentino, marcados por una suerte de "complejo de inferioridad arqueológica" frente a las grandes civilizaciones andinas, percibidas como lejanas -o incluso ajenas- con respecto al imaginario geográfico de la nación (centrado en la pampa) que se vuelve dominante (por ejemplo, en el ensayo Facundo -1845- de Domingo F. Sarmiento, o en el poema La cautiva -1837- de Esteban Echeverría).

4 En Les races aryennes du Pérou (editado primero entre 1865 y 1869 en la Revista de Buenos Aires, y publicado luego como libro en francés, con financiamiento de Justo J. de Urquiza y gracias a la traducción del egiptólogo francés Gaston Maspero), ${ }^{1}$ Vicente Fidel López busca resolver este dilema, clave para el pensamiento romántico y sobre todo para el contexto argentino, reivindicando el origen elevado de la civilización incaica, y confirmando su enorme expansión a lo largo del territorio nacional. Para esa legitimación (que responde a la obsesión de la época por determinar el origen -chino, fenicio, egipcio o incluso atlante- de los indios americanos), ${ }^{2}$ López se basa en la filología (por entonces, una ciencia muy prestigiosa, que promete develar los secretos del pasado más remoto, irrecuperables por otras vías), y en especial apela al modelo de la filología comparada del orientalista alemán Max Müller, abocado a probar el origen "indoeuropeo" o "ario" -sinónimos en la época- ${ }^{3}$ de las lenguas más "civilizadas". ${ }^{4}$ Para postular la matriz "indoeuropea" del quichua, López parte también de una sugerencia de Friedrich Schlegel, sobre la proximidad lingüística y cultural entre quichuas y pueblos de la India, explicable por una posible migración a América en tiempos remotos. $^{5}$

5 Pero además López desafía algunos límites del eurocentrismo implícito en la filología europea, aunque sin poner en cuestión el evolucionismo de fondo, hegemónico en la época (y funcional al imperialismo cultural que tiende a ser ejercido por la disciplina). ${ }^{6}$ En particular, rechaza la idea de Müller de que el quichua es una lengua aglutinante, propia de un estadío atrasado de desarrollo civilizatorio, y por ende incapaz de expresar la complejidad del pensamiento abstracto. ${ }^{7}$ Contra esta perspectiva, y apelando a los estudios comparados no solo en el campo de la filología, sino también en los de la astrología, la astronomía y la teología -entre otros saberes-, López advierte que el quichua es efectivamente una lengua indoeuropea (como el egipcio, el griego o el sánscrito), pero que al momento de migrar de Oriente a los Andes, aun se encontraba en un estadío aglutinante, previo al desarrollo de su forma flexiva más madura, aunque conservando el potencial civilizatorio indoeuropeo, lo que permitiría explicar el alto desarrollo alcanzado por las civilizaciones andinas.

Repitiendo un lugar común entre las legitimaciones paradójicas del indianismo romántico, la tesis de López sobre el origen "ario" de los incas (en principio poco exitosa en Argentina, pero significativa para otros intelectuales del continente en el mismo período), ${ }^{8}$ implica además una tranquilizadora arqueologización de la alteridad, ya que aquel pasado prestigioso contrasta con la decadencia actual de los indígenas, 
convertidos en "sepulcros vivos de la antigüedad americana" (López, 1865, p. 6), una vez perdidos los lazos con el origen "indoeuropeo".

7 Como detalle, vale la pena recordar que, a partir de la primera edición de Les races aryennes $d u$ Pérou, es posible establecer un fuerte contrapunto entre el ensayo romántico de López y la perspectiva "darwinista" de Bartolomé Mitre, dado el interés de este último por disputar la interpretación del mundo precolombino, ${ }^{9}$ en el contexto de un debate más amplio entre ambos autores, en torno a la interpretación de la historia argentina (y en definitiva, en torno a los modos de producir conocimiento historiográfico). ${ }^{10}$

8 Tres décadas más tarde, el médico francés -residente en Argentina- Heri Girois edita L'occulte chez les aborigènes de l'Amerique du Sud, en 1897 en francés, y en 1901 en español (en una versión ampliada en la que -además de incorporar nuevas ilustraciones y de agregar el subtítulo Los quechuas, raza ariana, acercando así más abiertamente su libro al precedente de López- incorpora más información etnográfica sobre guaraníes y araucanos, aunque continúa privilegiando el caso de los tiahuanacotas y de los quichuas). ${ }^{11}$

9 Inscripto en el marco de los esoterismos modernos de entresiglos, Girgois es el primer representante general de la Orden Martinista en Sudamérica, una escuela ocultista fundada en Francia por el médico Gérard Encausse (conocido en los círculos esotéricos como Papus, cuya obra más representativa es el Traité Méthodique de Science Occulte, de 1888) y difundida en América Latina gracias a figuras tales como el propio Girgois primero, y el alemán Arnold Krumm Heller después..$^{12} \mathrm{~A}$ pesar de la significativa escasez de datos biográficos sobre la figura de Girgois, es posible afirmar que toma contacto con el mundo indígena como médico cirujano de la llamada "Campaña al Desierto", integrando la columna de Marcelino Freire, y que luego funda en Buenos Aires una sede de la "Ecole Hermetique" de Papus, ofreciendo allí cursos sobre ocultismo, centrados entre otros temas- en el estudio del pasado prehispánico, diferenciándose así del cariz europeo propio del modelo francés para la misma institución. ${ }^{13}$

Basándose en López y en Müller, Girgois afirma que una raza extranjera como los pelasgos migró hacia América del Sur, gracias a la existencia de la Atlántida o de Lemuria en tiempos remotos. ${ }^{14}$ Estos antiguos Pirhuas habrían hablado una variante antigua del sánscrito, que al llegar aún presentaba la forma de una lengua aglutinante (Girgois, 1901, p. 14), pero con todo el potencial para acompañar el desarrollo de una importante civilización. Para demostrar el origen ario del quichua, revisa sintéticamente algunos sustantivos de esta lengua que convergen con sus equivalentes en sánscrito. ${ }^{15}$ Prolongando así la pulseada iniciada por López frente a los lingüistas europeos como Müller, argumenta que el quichua es una lengua aria separada de su tronco madre antes de volverse flexiva, permaneciendo en estado aglutinante como etapa transitoria hacia la flexión, ${ }^{16} \mathrm{y}$ que por ende se trata de una lengua completa, que se adapta a las necesidades expresivas de la civilización y del pensamiento abstracto.

\section{De la lengua a la cultura}

11 Siguiendo el ejemplo dado por López en la segunda parte de Les races aryennes..., Girgois busca demostrar que los antiguos peruanos trajeron del Asia boreal el mismo zodíaco que recibieron los griegos de las tribus arias. Pero a partir de este punto de contacto, Girgois despliega una operación comparativa mucho más amplia que la de su antecesor 
pues, lejos de detenerse en el análisis filológico y en el astrológico, aborda mitos y leyendas, formas de organización social, y especialmente conocimientos esotéricos que incluyen desde ritos de magia hasta prácticas médicas y farmacológicas muy diversas. Así por ejemplo, Girgois acumula argumentos arquitectónicos, teogónicos y médicos entre otros- para demostrar el origen ario de tiahuanacotas y quichuas, ${ }^{17}$ al tiempo que -al igual que López- en un abierto impulso nacionalista, se esfuerza por probar la extensión de esas "civilizaciones", derramadas ampliamente desde el NOA sobre gran parte del territorio argentino. ${ }^{18}$

12 La fascinación de Girgois por revisar el continuum de prácticas vinculadas a lo oculto, entre los diversos grupos indígenas, termina desplazando a un segundo plano el objetivo genealógico inicial, fundado en la obsesión compartida con López, por demostrar el origen indoeuropeo de la cultura quichua. Más bien, el interés ahora consiste en comprobar la profunda compatibilidad de fondo entre los esoterismos de Oriente, de Occidente y del mundo precolombino, en base no solo al origen compartido en un tiempo histórico remoto, sino también en función del desenvolvimiento de un mismo Espíritu que accede a lo oculto como conocimiento universal.

En este punto, converge plenamente con los principios teóricos del esoterismo al que Girgois adhiere abiertamente, al esforzarse por establecer denominadores comunes entre varias corrientes espirituales de diferentes épocas, en sintonía con la creencia en una Prisca Theologia, entendida como el conocimiento de una verdad primordial, común a toda la humanidad y practicada desde sus orígenes remotos. ${ }^{19}$ En este sentido, Girgois prolonga una vasta tradición de pensamiento -prolífica en el período colonial-, fundada en la postulación neoplatónica de una única teología, subyacente a todas las religiones, y que valora especialmente las formas más puras del pasado remoto, esforzándose por recuperarlas en el presente..$^{20}$ Llevado hasta sus últimas consecuencias, este razonamiento permite incluso considerar el paganismo del pasado (de figuras nodales como el dios andino Wiracocha o el dios mexica Quetzacóatl) como potencialmente superior respecto del cristianismo. Sobre ese tipo de tradiciones esotéricas, divergentes respecto del modelo estrictamente europeo, descansan perspectivas americanistas como la de Girgois, al afirmar la necesidad de incluir los esoterismos indígenas precolombinos en el concierto esotérico universal, e incluso al subrayar su pureza originaria como garantía de una mayor autenticidad. ${ }^{21}$

Impulsado por este objetivo, Girgois dejó en segundo plano la preocupación por el origen indoeuropeo de los grupos andinos, para sumergirse en la enorme cantera de los conocimientos esotéricos provistos por los grupos quichua, araucano y guaraní. Dicho en otros términos, la hipótesis historicista parece desdibujarse, al menos por momentos, ante la evidencia de un conocimiento esotérico universal, revelado por medio de la intuición.

\section{Símbolos americanos o símbolos arios}

Ahora bien; puesto a debatir por qué algunos símbolos gravitan en todas las culturas indígenas de América, Girgois oscila entre retomar la explicación histórica (sobre la migración indoeuropea y sobre los contactos culturales en el continente), y volver sobre la idea de una intuición esotérica universal. En este sentido, la interpretación de la cruz americana constituye un punto especialmente sensible en su argumentación, porque implica el establecimiento de una disputa velada con respecto al análisis 
contemporáneo del mismo símbolo, por parte del arqueólogo argentino Adán Quiroga, estudioso amateur del legado precolombino del noroeste argentino. En efecto, en su ensayo La cruz en América (editado en 1901, el mismo año en que Girgois publica su libro en español), Quiroga se propone explorar la gravitación de ese símbolo precolombino en distintas culturas. Sumergido en la hermenéutica de la plástica indígena, confirma la existencia de una sólida unidad continental, por la convergencia de ese mismo símbolo, con el mismo significado, entre los grupos más distantes del continente. Fascinado por las cosmovisiones indígenas (y por el potencial de los estudios de mitología comparada, en base a la misma perspectiva de Müller, compartida por Girgois), Quiroga advierte que la cruz precolombina representa el cruce de los cuatro puntos cardinales (incluidos los cuatro vientos) como claves para la producción de la lluvia, sagrada por la importancia de este recurso para la supervivencia. Con una mesura hermenéutica notable para la época, Quiroga acumula pruebas sobre la coincidencia en el empleo de la cruz (de dos líneas iguales) como símbolo espacial y acuático, así como también se refiere a las aves como símbolo de las nubes, de las serpientes como símbolo de los rayos, o de los sapos como símbolo del agua. En la alfarería y en los textiles que analiza, estas figuras a menudo se combinan entre sí para reforzar la misma invocación de la lluvia, ya que la cruz -dice Quiroga- "se vuelve el símbolo sintético de todos los accidentes y fenómenos atmosféricos" (Quiroga 1942 [1901], p. 246). Por eso las divinidades climatológicas en América (desde Tláloc o Quetzacóatl a Huitzilopotchli o Viracocha -e incluso divinidades locales como la figura mapuche de Pillán o la calchaquí de Huayrapuca-) llevan el mismo emblema de la cruz, o ellas mismas forman cuaternos sagrados, porque "la lluvia es el motivo fundamental de la religión, y la cruz su símbolo" (Quiroga 1942 [1901], p. 246).

Si Quiroga conserva la moderación en sus hipótesis, especulando por ejemplo que la gravitación continental del mismo símbolo solo puede deberse al contacto histórico de estos pueblos entre sí, Girgois insiste en su esoterismo orientalista, advirtiendo -sin citar a Quiroga- que la cruz no representa los cuatro puntos cardinales, ${ }^{22}$ sino que evidencia tanto el origen ario de los quichuas, como el derrame de esa alta cultura sobre los demás grupos del continente.

Cuando retoma su esfuerzo por demostrar la matriz indoeuropea de los quichuas, y la expansión de esa matriz por el resto del continente, Girgois sugiere el posible origen quichua de varias prácticas araucanas y guaraníes, ${ }^{23}$ diseñando así una suerte de "imperialismo arqueológico" de matriz "andinocéntrica" a nivel regional. E incluso llega a sostener que los indígenas mexicanos descienden de los quichuas; que estos últimos con seguridad migraron hacia el norte, siendo imposible una migración opuesta por motivos varios, incluidas las dificultades de navegación desde México. ${ }^{24}$ Poniendo en evidencia además, a cada paso, la legitimación regional -y nacional- implícita en su tesis, concluye que los quichuas no solo no han migrado desde México, "como algunos etnógrafos han querido hacerlo creer", sino que de hecho "los quichuas argentinos $y$ peruanos no son aborígenes" (Girgois, 1901, p. 31; bastardilla nuestra), sino arios en sentido amplio.

\section{Entre el evolucionismo y el relativismo cultural}

En principio, como vimos, Girgois privilegia la jerarquía racial y cultural del mundo andino, por encima del resto de los grupos indígenas sudamericanos, y se limita a 
abordar solo los grupos que habitan el territorio argentino, homogeneizándolos bajo los modelos quichua, araucano y guaraní. En este punto, Girgois inscribe su discurso en el seno de una tradición "andinocéntrica" (integrada por López, entre otros precursores) que tendrá también largo aliento a posteriori, fundada en el reconocimiento de ese imponente legado arqueológico prehispánico -superior a otros sustratos indígenas del continente-, en la supuesta docilidad indígena para aceptar la dominación colonial -forjando vínculos de convivialidad "armónica", contrastantes con la belicosidad de los grupos patagónicos y chaqueños-, y en el compromiso de ese campesinado indígena con las luchas por la emancipación respecto de España. ${ }^{25}$

Además de preservar el prestigio del pasado solo para las grandes civilizaciones andinas, y de imaginar un derrame "imperialista" de esa alta cultura hacia los grupos "inferiores" (incluyendo allí "otras grandes culturas" como la tolteca), Girgois subraya la decadencia actual de los indígenas en general, incluidos los quichuas, en contraste con su esplendor pasado. En este punto, su ensayo vuelve a empalmar con una larga tradición discursiva, que se remonta al menos hasta los románticos de principios del siglo XIX, y desemboca en los diagnósticos que celebran -o lamentan- la condición de "decadencia" -o de "barbecho"- de estos pueblos "dormidos" o "en extinción", incluso en el marco de la antropología científica de la década de $1940 .{ }^{26}$

En sintonía con esta matriz discursiva, Girgois sostiene que los tres grandes grupos que habitan la Argentina se encuentran "en vías de desaparecer, sea mezclándose con los colonos o diezmados por el alcohol" (Girgois, 1901, p. 22), o insiste en señalar que, en el presente, los araucanos forman un "pueblo degenerado" en contraste con sus antepasados, "sumamente poderosos, dotados de una civilización relativamente desarrollada, que les permitió contrarrestar varias veces el poder de los Incas, sus dueños y señores" (Girgois, 1901, p. 23). Mayor contraste presentan los actuales quichuas, "que no son esclavos como sus hermanos los araucanos sometidos, pero creemos que su estado de miseria es más lamentable" porque han heredado una "antigua y esplendorosa civilización" (Girgois, 1901, p. 25) que hoy recuerdan, sumergidos en la explotación y en la degradación intelectual.

21 A pesar de (o junto con) estos rasgos evolucionistas, el ensayo de Girgois contiene algunos desvíos significativos respecto de los discursos hegemónicos. Por un lado, aunque el tratamiento de los tres grupos indígenas es asimétrico (por el privilegio indiscutible dado al mundo andino), no deja de considerar también a los araucanos y a los guaraníes, valorándolos por la riqueza de sus saberes esotéricos, en sintonía con la de los antiguos peruanos. Su apertura hacia estos otros casos, el cuidado con que describe sus prácticas médicas y mágicas, y el tono respetuoso con que repone esa información, instauran una distancia considerable con respecto a los discursos dominantes en esta etapa. ${ }^{27}$ Así, aunque se mueve dentro del evolucionismo eurocéntrico para jerarquizar los grupos en el pasado, y para contrastar el esplendor prehispánico con la decadencia actual, Girgois también da cuenta de un relativismo cultural atípico para la época, por la apertura con que acepta la diferencia cultural, en contraste con la mayoría de los autores contemporáneos abocados al estudio de las supersticiones populares en general. ${ }^{28}$

Si bien -como vimos- El oculto... realiza una simplificación reduccionista de los subgrupos, sumergiéndolos además en una temporalidad abstracta que pierde de vista la experiencia del mestizaje colonial, no solo mantiene una actitud respetuosa sobre esas prácticas, sino que además valora algunos saberes (especialmente los vinculados a 
la medicina, la farmacopea, la magia y otras formas del esoterismo), considerándolos equivalentes a otras prácticas semejantes orientales y occidentales, tanto del pasado remoto como del presente.

Cabe aclarar que la legitimación de las culturas indígenas, por la remisión a una genealogía prestigiosa que entronca con los antepasados de Grecia, Etruria o la India, se extiende entre algunos autores más allá de la línea que establecen López y Girgois, incluso para salvar a otros grupos alejados respecto de los linajes andinos (como en el caso del zoólogo francés Ferdinand de Lahille, empeñado en reivindicar el origen prestigioso de los onas), ${ }^{29} \mathrm{y}$ perdura por varias décadas, a pesar de -o junto con- los embates de la antropología científica más moderna, encarnada por José Imbelloni y su método histórico-cultural.

\section{Medicinas y magias indígenas}

Basándose en ese relativismo atípico, Girgois apela a su propia autoridad científica como médico, para confirmar la existencia de un conocimiento médico y farmacéutico válido especialmente entre los kollas andinos y las machis araucanas, comprobado por su propia experiencia (por ejemplo, al observar a las machis curar no solo infecciones sino también fracturas múltiples, recomponiendo exitosamente miembros destrozados; Girgois, 1901, p. 156).

Ese saber médico y farmacológico indígena, que requiere de un largo aprendizaje ${ }^{30}$ (y que ha sido celosamente preservado, a pesar de la explotación extrema a la que fueron -y continúan siendo- sometidos los indios), fue duramente reprimido durante la evangelización de América, y aun es perseguido en el presente "gracias a la guerra ignorante que les hacen los médicos" (Girgois, 1901, p. 265). Buscando intervenir abiertamente en el debate contemporáneo en torno del alcance del conocimiento científico, incluso advierte que los kollas que llegan a formarse luego en las facultades de medicina, para legalizar su saber, "son sin contradicción alguna mejores, de una experiencia mayor que sus demás colegas mestizos y extranjeros" (Girgois, 1901, p. 265), a tal punto que muchas personalidades de la elite porteña confían más en los médicos kollas que en los científicos de renombre.

Esforzándose por preservar los nombres chamánicos de los diversos grupos (para evitar así la imposición del concepto europeo y descalificador de "brujo"), ${ }^{31}$ Girgois afirma la eficacia empírica de algunas prácticas, no solo médicas sino también mágicas y adivinatorias entre los indios. Así por ejemplo, afirma que el cacique Numen Curá huyó de la persecución del Ejército gracias a una machi que, en trance, pudo anticipar cada ataque del enemigo, y en otro pasaje se detiene en el respeto reverencial que reciben, entre los araucanos, las ofrendas y los walichos colgados por las machis en los árboles sagrados. De hecho, llega a confirmar la fuerza esotérica de la magia indígena al contar que, cuando era cirujano del Ejército durante la "Campaña al Desierto", él mismo comprobó en Guaminí que, cuando los soldados derribaron un árbol sagrado, cargado durante dos siglos con walichos o kati (espíritus de enfermedades conjuradas por las machis),... todos los que intervinieron en ese acto perecieron misteriosamente, ahogándose en la laguna al desatarse una tormenta imprevisible. Además, recuerda que Guaminí era especialmente defendido por Namuncurá, precisamente por el valor religioso de ese sitio. Para explicar este fenómeno, apela a la voluntad psíquica de las machis y al temor de todas las comunidades indígenas del área, elementos que -según 
él- crean un campo de fuerzas psíquicas contenidas, que se liberan para vengar el sacrilegio de su destrucción.

La ausencia de juicios valorativos, el respeto por las auto-designaciones, y sobre todo la afirmación de la eficacia de la magia y la adivinación indígenas, contrastan de manera flagrante con respecto a la condena patologizante de las mismas prácticas por parte de la medicina occidental contemporánea (a la cual Girgois deslegitima, por la soberbia implícita en negar saberes fundados en la intuición, y válidos desde tiempos remotos). ${ }^{32}$

Además, para el autor de $E l$ oculto..., quichuas, guaraníes y araucanos poseen una farmacopea valiosísima de la que dependen las naciones civilizadas para curar en el presente, como en el caso del empleo de la quina, los bálsamos, la ipeca, el vinal y la coca, entre otras sustancias conocidas y otras aun no descubiertas por los exploradores.

En definitiva, para defender la sensibilidad implícita en numerosas prácticas indígenas, Girgois busca amparo en una tradición discursiva alternativa respecto del eurocentrismo, para desde allí poner en crisis explícitamente las connotaciones atribuidas a la dicotomía "civilización" / "barbarie". Así por ejemplo, explicitando su lazo con el relativismo cultural de Lucio V. Masilla, de quien se considera su continuador (por ejemplo en su alegato final en defensa de los indios; Girgois, 1901, p. 334), Girgois elogia, entre los quichuas, la mayor equidad de poder entre varones y mujeres en el matrimonio, así como también la mayor libertad sexual de las mujeres solteras entre los araucanos, al tiempo que subraya la belleza de las indias en general, en un gesto que demuestra su esfuerzo por poner en cuestión los parámetros eurocéntricos del deseo masculino, tan presente en la literatura de viajes de esta etapa. También valora el coraje de los indios frente a enfermedades como la viruela (por ejemplo, al recordar una vivencia personal en el marco de la "Campaña al Desierto", cuando en 1879 se desató una epidemia entre los indios cautivos, y una machi arriesgó su vida con entereza para cuidarlos a todos).

El relativismo de Girgois se completa con una condena abierta de la Conquista y de la continuidad de la explotación indígena en el presente, como experiencias nefastas que arrasan con un orden económico, social y político justo, y con un arte y una religión elevados. En efecto, si bien elogia tangencialmente la eficacia militar de la "Campaña al Desierto", subrayando el papel jugado por los soldados argentinos o por sus jefes (como en el caso de Marcelino Freire, a quien Girgois acompaña en 1879), también denuncia esa represión, cuando advierte que "sin combates serios, han sido capturados, incorporados al Ejército los adultos, distribuidas las mujeres, niños y niñas a quienes las socilitaban, [dando lugar a] la esclavitud bajo el nombre de civilización" (Girgois, 1901, p. 23). Si bien ese alegato se despliega en varios momentos del ensayo, reconociendo sobre todo la entereza moral de los indios a pesar de su condición de explotados, ${ }^{33}$ alcanza el climax en el apartado "Los indios y la civilización" -precisamente en el cierre del ensayo-, cuando Girgois asume un tono más abiertamente igualitarista -y francamente atípico en el contexto argentino de la época-, para denunciar los abusos que siguen cometiéndose en el presente. Empalmando con el denuncialismo de otros intelectuales vinculados al indianismo andino -como en el caso de la escritora peruana Clorinda Matto de Turner- ${ }^{34}$ advierte que incluso en países como la Argentina, que tienen la igualdad como base de su Constitución, los indios son tratados como animales, retenidos "en la servidumbre para mengua de nuestra civilización" (Girgois, 1901, p. 331), y sumergidos en la ignorancia para que no reclamen sus derechos. Entonces advierte que, tanto en la Conquista como ahora, "les trajimos los vicios [...]; les hemos 
robado sus territorios, pues ellos eran los dueños por derecho de primeros ocupantes", y, por ende, "tiempo es ya que terminen esos crímenes de lesa humanidad [...]. Se ha acabado con la esclavitud del negro; pongamos fin a la servidumbre y explotación del indio" (Girgois, 1901, p. 332; bastardilla nuestra). Con una retórica crecientemente exaltada, interpela a "vosotros, comerciantes en civilización" (Girgois, 1901, p. 333), acusándolos de destruir el legado prehispánico, formado por obras artísticas irreproducibles en Europa, monumentos arquitectónicos y caminos admirables, o sistemas políticos como el de los incas, que permitía administrar a más de 12 millones de habitantes, manteniéndolos conformes "con el gobierno casi comunista de los Pirhuas antiguos [...], que aseguraba la felicidad de todos" (Girgois, 1901, p. 334), además de perseguir a los amautas como astrólatras y a los kollas como supersticiosos, en lugar de aprender de su experiencia. Girgois reclama entonces frenar la inmigración europea e incentivar en cambio el trabajo indígena, aprovechando su fuerza productiva mediante la educación.

31 En este punto, aunque Girgois no llega a reconocer la paradoja que implica reconocer la riqueza cultural indígena como diferencia, y a la vez fomentar la inclusión pedagógica de estos sujetos (lo cual por entonces supone, casi sin excepciones, imponer una homogeneización des-etnizante), su gesto contrasta significativamente con respecto a los discursos dominantes en la época, que declaran la inviabilidad de los indígenas en una nación moderna, o que reclaman su urgente dilución gracias a la inmigración europea, por la vía del mestizaje.

Por lo demás, el relativismo cultural de Girgois también flaquea frente a ciertas prácticas, especialmente entre los indígenas de la selva chaqueña y de la Patagonia. Así por ejemplo, su respeto por las medicinas "otras" trastabilla cuando narra el sacrificio de una yegua entre los tehuelches, para curar a un enfermo, pues una vez extraído el corazón del animal, la ceremonia deriva en una bacanal perturbadora de violencia y alcohol, saturada de clisés eurocéntricos sobre el salvajimo del "otro". ${ }^{35}$

\section{La nostalgia frente a las jerarquías armónicas}

33 Uno de los puntos en los que se basa para defender la universalidad de lo oculto y el origen indoeuropeo del mundo andino remite a las formas jerárquicas comunes aplicadas a la organización social, defendidas por Girgois como imprescindibles para sostener el orden, incluso en el presente. Así por ejemplo, señala la convergencia de la organización social pirhua y quichua por una parte, y la griega, la egipcia, la etrusca y la hindú por otra, en base a la existencia -en todos los casos- de cuatro jerarquías (sacerdotes, soldados, agricultores y pastores).

En su perspectiva, el mundo andino se presenta como un orden utópico estable y libre de conflictos sociales, ${ }^{36}$ dejando entrever -por contraste- el temor frente a la sociedad babélica del presente, dado el "aluvión inmigratorio" y la movilidad social angustiante -entre otros elementos- que presionan peligrosamente por la ampliación de las bases democráticas.

Esa convivialidad armónica en el pasado precolombino alcanza el climax en prácticas tales como las procesiones religiosas, las fiestas agrarias y los funerales de personas importantes, que Girgois evoca como escenas espectaculares -muy estilizadas- de comunión colectiva. Así por ejemplo, la fiesta del Umu Raymi, santo misterio del Sol, es descripta como una ceremonia teatral cargada de connotaciones espirituales, donde 
cada estamento tiene su lugar bien definido, y donde todos participan transidos por un mismo sentido trascendente (Girgois, 1901, p. 90).

En la evocación de esas prácticas, se juega tanto la admiración por las jerarquías sociales como la fantasía del propio esoterismo moderno, pensado como una vía capaz de revivir las raíces primigenias de la comunitas (nacional y acaso también continental), recuperando el ideal de una fraternidad espiritual milenaria, por encima de la conflictividad social inter-clase. Ese estudio de las fiestas prehispánicas explícitamente abre vasos comunicantes con el presente, por ejemplo en casos como la fiesta inca de Chirapa, que invoca la lluvia durante la sequía del verano: allí el juego con agua manifiesta su afinidad no solo con algunas festividades en la India, sino también con el carnaval moderno celebrado en toda Sudamérica, demostrando así la vitalidad del sustrato precolombino, y la potencialidad de esas instancias para crear comunión en el presente. $^{37}$

Al mismo tiempo, siguiendo el modelo prehispánico, Girgois defiende la separación jerárquica entre los saberes esotéricos de la elite y los del vulgo en el presente, ya que lo oculto debe permanecer vedado para las masas, solo preparadas intelectualmente para incorporar los resultados prácticos de esas formas de conocimiento. ${ }^{38}$ En efecto, aunque reconoce el riesgo de que la clase sacerdotal tenga extremo poder en las comunidades indígenas (por ejemplo, controlando al pueblo a través de sus augurios), la democratización del saber esotérico crece sobre todo en el presente, volviéndose un verdadero "mal del fin de siglo", al mercantilizar un conocimiento arcano tan poderoso. Poniendo en evidencia la amenaza -no solo esotérica sino también políticaimplícita en esa democratización, Girgois da el ejemplo de la peligrosa difusión del saber alquímico sobre la dinamita. La igualdad es entonces, para Girgois, una nivelación hacia abajo que retrasa -e incluso impide- el avance del conocimiento, y que pone en riesgo la estabilidad social y política. Extendiendo su defensa de las jerarquías (del mundo del conocimiento esotérico a la sociedad en general), advierte que "el olvido de las jerarquías [es] la causa primordial de las dificultades sociales que trastornan a todas las naciones" (Girgois, 1901, p. 200). E incluso, consciente del modo en que su propio libro rompe riesgosamente el cerco de ese elitismo esotérico, al difundir saberes vedados, Girgois asume varias veces una posición abiertamente evasiva, para preservar secretos que se volverían una amenaza en manos del lectorado masivo. ${ }^{39}$ Se hace evidente entonces que, en esa defensa de las jerarquías esotéricas, se refracta una adhesión a la "elite del talento", compatible con la desplegada por parte de otros intelectuales contemporáneos (tal como ocurre, por ejemplo, en el caso del positivista contemporáneo José Ingenieros quien, en textos tales como $\mathrm{El} \mathrm{hombre} \mathrm{mediocre,} \mathrm{difunde}$ la admiración y la imitación del "hombre de genio" por parte de las masas, preservando la condición de "genio" para una pequeña elite intelectual, impugnando además explícitamente- los efectos de la democracia política). ${ }^{40}$

Como contraparte de (o junto con) la defensa del elitismo, Girgois lamenta el acceso limitado a los saberes de los indígenas en el pasado, porque solo se han conservado bajo la mediación de los cronistas católicos que registran -y al mismo tiempo condenanestas prácticas como "demoníacas", distorsionándolas. 


\section{Ciencia y esoterismo}

Confirmando tesis como la de Quereilhac (2016) sobre la relación compleja entre ciencia y esoterismo en entresiglos (incluyendo la concepción del ocultismo como el componente esotérico de la propia ciencia, y por ende, reconociendo la aspiración del ocultismo a integrar ciencia moderna y fenómenos esotéricos en una unidad sincrética), en su prólogo Girgois declara abiertamente que escribe El oculto... para responder al interés contemporáneo de la ciencia por lo oculto y por los fenómenos psíquicos en general.

40 Un punto central en la articulación de esas instancias remite al fenómeno de la sugestión, convertido en el principal recurso aplicado por la psiquiatría de la época, para revertir síntomas histéricos, en el marco de una abierta y candente disputa con curanderos y chamanes del mundo popular (en general, acusados de ejercicio ilegal de la medicina). ${ }^{41}$ Pues bien; en el marco de la integración "fraterna" de saberes arcaicos y modernos (que propicia el Martinismo al que adhiere Girgois), El oculto... exalta enfáticamente el profundo conocimiento médico de los chamanes indios (desde los antiguos tiahuanacotas hasta los indígenas del presente), para curar enfermedades por sugestión y por magnetismo.

41 Esta perspectiva de Girgois debe ser reinscripta en el contexto enunciativo de entresiglos, signado por una candente discusión, entre psiquiatras y esoteristas, en torno del problema de la hipnosis. Vale la pena recordar que la psiquiatría desarrollada por el francés Jean Martin Charcot y por los miembros de su "Escuela de la Sapêtrière" (hegemónica en la época, y muy difundida en los medios locales a través de la obra de Ingenieros y de la revista Archivos de psiquiatría y criminología, fundada un año después de la edición de El oculto...), experimentan centralmente con la hipnosis como sugestión inconsciente, para volver reversibles los síntomas histéricos, al tiempo que consideran como "histeria" las manifestaciones religiosas vinculadas al éxtasis y la posesión, provocando así una fuerte secularización -patologizante- de los discursos místicos del pasado y del presente. ${ }^{42}$

Girgois interviene en este contexto, asumiendo una clara posición de resistencia contrahegemónica, al retrotraer la sugestión al concepto previo de "magnetismo", afín al vocabulario esotérico (y rechazado por la psiquiatría positivista -que, en Europa, acaba de descubrir la hipnosis a partir del magnetismo, por entonces muy difundido en la cultura popular-). Insistiendo en esta dimensión indirectamente resacralizadora, Girgois explica las curas efectivas, por parte de los chamanes indígenas, como resultado de la carga energética o de la manifestación del "astral", capaz de provocar un "sueño magnético" que revierte los síntomas de la enfermedad. En definitiva, profundizando su relativismo cultural, insiste en la compatibilidad de fondo entre chamanismo y psiquiatría contemporánea. Por lo demás, al abordar el ejercicio de la medicina indígena, Girgois enfatiza el esfuerzo de los chamanes por mantener vivos $-\mathrm{y}$ en secreto- esos saberes arcanos, a pesar de la miseria y de la esclavitud en la que se encuentran, y de exponerse además a otros peligros por el solo hecho de entrar en contacto repetidamente con "fuerzas extrahumanas y suprafísicas" (Girgois, 1901, p. 297).

43 Aun teniendo en cuenta la divergencia teórica entre "magnetismo" e "hipnosis", la convergencia en el reconocimiento de la sugestión, por parte del chamanismo tanto como de la psiquiatría contemporánea, impulsa a Girgois a confiar en nuevas 
comprobaciones científicas a futuro, sobre los fenómenos esotéricos aun no probados por la ciencia. De hecho, el concepto amplio de "medicina" al que apela, incluyendo la homeopatía y el energetismo -entre otras prácticas-, le permite confirmar más fácilmente la existencia de un continuum no solo entre esoterismo indígena y esoterismo occidental, sino también entre ambos esoterismos y la ciencia. En este sentido, Girgois confía en que el avance científico permitirá ir comprobando las verdades del conocimiento arcano. Incluso, acumulando argumentos en esta dirección, repite un tópico común al esoterismo de la época, cuando recuerda el ejemplo modélico de la fotografía, que recientemente habría podido captar empíricamente el modo en que un cuerpo irradia su "astral" en la atmósfera, validando así lo sostenido por los esotéricos, tanto indígenas como occidentales.

\section{Embestidas cientificistas}

44 Pocos años después de publicado El oculto..., el antropólogo ítalo-argentino José Imbelloni (en los inicios de una carrera profesional que lo consagrará, durante el primer peronismo, como una de las principales voces de la antropología oficial) arremete contra el espiritualismo indianista y "residual" (de figuras como López y Girgois), presentado como parte de un americanismo anticientífico que debe ser desterrado. ${ }^{43}$

En particular, en "Dos americanismos" (1922), Imbelloni se queja de que "el público, en general, no está dispuesto a seguir un crecimiento tan lento [como el del americanismo cientificista]", ${ }^{44} \mathrm{y}$ frente al americanismo "heroico" hacia el que se inclinan las masas (que fomenta insólitas correlaciones entre culturas), sentencia que "todo pueblo, como todo hombre, cultiva y honra el americanismo que se merece". Convencer a ese público masivo sobre la verdad del método histórico-cultural será, desde entonces, una meta clave de Imbelloni. Poco después, en La esfinge indiana (1926), insiste en interpelar a un público amplio, para demostrar la verdad científica acerca de los contactos culturales efectivos, en desmedro de las hipótesis inverosímiles que, con gran éxito, circulan en tratados pseudocientíficos, artículos periodísticos y literatura de masas en general, especulando sobre migraciones insólitas como la de los "proto-indoeuropeos" que habrían llegado a América, atravesando continentes perdidos como la Atlántida o Lemuria.

De hecho, uno de los volúmenes que Imbelloni privilegia al editar su colección Humanior es el Libro de las Atlántidas, ya que por entonces el objeto de estudio de ese texto continúa siendo lo que Angenot (2010) define como un "ideologema": un punto nodal en el que convergen diversos discursos sociales contemporáneos, estableciendo una lucha por la imposición de un sentido hegemónico.

Desde la introducción general a la biblioteca, es posible percibir en qué medida Imbelloni es consciente del rédito de este tema para acercar a los lectores al resto de la colección: allí el director advierte que "uno de los tomos [...] destinado a interesar más prontamente al público [...] trata de la Atlántida, viejo tema, pero siempre cautivante, entre los de la mitología americanista" (Imbelloni, 1936, p. 9). En efecto, el mito de la Atlántida gravita en los años veinte en la literatura de masas, en las doctrinas esotéricas, e incluso en el campo antropológico, donde difusionistas como Leo Frobenius (a quien se afilia Imbelloni) entreven los contactos culturales que consideran "efectivos" en la historia, latentes bajo las deformaciones del mito, e incluso 
encuentran la oportunidad de conducir hacia la disciplina científica la pasión sugestiva que despierta ese mito en el lectorado masivo. ${ }^{45}$ De hecho, Imbelloni subraya que la Atlántida está viva especialmente "en lo más recóndito de la mente de los Americanos" (Imbelloni y Vivante, 1939, p. 8), por "la fuerza sugestiva que dimana del sinnúmero de símbolos, correlaciones, asociaciones, intuiciones y otros procesos subjetivos [...] suscitados por los escritores que explotan la afectividad y la sensibilidad de las grandes masas populares" (Imbelloni, 1939, p. 388).

De este modo, Imbelloni perfila una suerte de "americanismo anti-americanista" que apunta a "situar la humanidad americana" (y, sobre todo, al Indio, objetivado con mayúsculas, como una categoría transhistórica) "en el justo lugar que le corresponde". La construcción de ese "justo lugar" incluye además la confirmación de las jerarquías dominantes para las culturas indígenas, elevando el "complejo cultural méxico-andino" a la altura de las grandes civilizaciones proto-históricas del Viejo Mundo, muy por encima de las de otros grupos "inferiores".

Cuestionando el romanticismo en sentido amplio, Imbelloni ataca especialmente los inicios del movimiento romántico stricto sensu, responsabilizando a Volney -entre otros autores- por la idealización de los pasados remotos que luego fomenta el romanticismo. ${ }^{46} \mathrm{Su}$ crítica cientificista a los indianismos románticos y a los indianismos posteriores (definidos en "Dos americanismos" como parte de un mismo "americanismo heroico") atenta especialmente contra correspondencias como la establecida por López en su ensayo de 1871, entre el quichua y el griego, para legitimar a los antepasados indígenas, "arianizándolos". Y agrega que la misma "forunculosis arianocéntrica" tienen otros autores, como el romántico brasileño Couto de Magalhães para el caso de los indios tupi. Para Imbelloni, ese americanismo estéril acumula pruebas insustanciales, careciendo de concordancia en sus conclusiones, por lo que debe ser superado.

Además de confirmar las jerarquías raciales y la "lucha por la vida", el "neohumanismo" que embandera Imbelloni (por ejemplo en la fundamentación con que inaugura en 1936 su colección Humanior del americanista moderno) se combina con una fuerte descalificación cientificista de los idealismos, entre los que incluye el pensamiento utópico europeo, la idealización barroca de la naturaleza y el hombre americanos, la visión romántica de la alteridad, e incluso las reivindicaciones indianistas de carácter emancipatorio en el presente, ${ }^{47}$ en un arco que podría incluir desde la perspectiva López hasta el "peligroso" elogio del comunismo incaico por parte de Mariátegui, sumándose a la activación de las masas campesinas en el marco de la Revolución Mexicana.

51 Más adelante, en "La formación racial argentina" (editado en el volumen oficial Argentina en marcha de 1947), Imbelloni responde a una consulta explícita, de parte del gobierno, sobre la delicada cuestión del poblamiento del país. ${ }^{48}$ Allí defiende el proyecto inmigratorio en curso (y aconseja en especial la inmigración latina, más acorde al carácter nacional), pero también contribuye con una especie de traducción científica, en clave racialista, del ideal de "comunidad organizada", al subrayar cómo la propia existencia del peronismo prueba la tendencia de las masas nacionales a homogeneizarse, al tiempo que naturaliza el liderazgo de Perón, en el marco de una teleología biológica que reformula el revisionismo histórico, en clave racialista.

52 En ese ensayo, además, Imbelloni evalúa la insignificancia de los indígenas como fuerza productiva, aconsejando al Estado promover la inmigración latina, reduciendo a los indios a un elemento meramente residual. Así por ejemplo, sentencia que "lo más 
pintoresco de esta prédica [indianista] es que por 'indios' entiende a los araucanos de la llanura, fragmentos dispersos y profundamente degenerados por amixia de un viejo núcleo central, de los que ya no es posible esperar nada, y los coyas del Noroeste, algo menos ralos pero igualmente envejecidos como raza y cultura" (Imbelloni, 1947, p. 288). Ese diagnóstico negativo sobre los indígenas como fuerza de trabajo puede completarse con la visión implícita en otras fuentes suyas de esta etapa, aproximándose además aunque sin converger plenamente- con las visiones de lo indígena presentes en otros discursos oficiales contemporáneos. ${ }^{49}$

En otros trabajos, además, Imbelloni analiza algunas cosmovisiones indígenas, desde una perspectiva científica que merece ser comparada con la esotérica de Girgois. Así por ejemplo en "La Weltanschauung de los Amautas reconstruida: formas peruanas del pensamiento templario" (1942), reconoce la importancia del "complejo cultural méxico-andino", que alcanza un grado de desarrollo significativo (incluyendo una "inspiración teocrática y astrolátrica" convergente), superior -a su criterio- respecto del resto de los grupos indígenas del continente. Para Imbelloni, los grupos de este complejo desarrollan un "pensamiento templario", con un verdadero sistema protocientífico que incluye desde una división del espacio muy elaborada, hasta una concepción del tiempo que implica calendarios precisos, e incluso una cronología mítica de Edades (con cuatro sucesivas destrucciones del mundo). Para Imbelloni, ese "pensamiento templario" llega a un grado de abstracción muy elevado, aproximándose por ende al conocimiento científico, aunque por su carácter mítico y proto-histórico permanece por debajo de la racionalidad científica. Desde este punto de vista, si bien tanto Imbelloni como Girgois reconocen la complejidad admirable de estas cosmovisiones, mientras Imbelloni repone las jerarquías racionales, Girgois subraya el papel de la intuición como forma privilegiada de conocimiento del mundo, y por ende defiende el abandono de esas jerarquizaciones occidentales, para reconocer la importancia de todas las manifestaciones de "lo oculto".

Algunas consideraciones finales

El esfuerzo de Girgois, como antes el de López, por corregir el error de los lingüistas europeos, al reconocer el potencial civilizatorio del quichua en base a su remoto origen prestigioso, configura un movimiento paradójico, típico de varios indianismos latinoamericanos del siglo $\mathrm{XX}$, que implica no poner en cuestión el eurocentrismo presente en el discurso hegemónico, sino más bien corregir las teorías centrales, reivindicando el derecho a la civilización por parte de los antiguos indígenas americanos. $^{50}$

El modo en que Girgois idealiza el orden jerárquico en la sociedad precolombina, en paralelo al respeto por las jerarquías en las órdenes esotéricas, deja entrever el temor ante las posibles disputas por el poder en el presente, dada la movilidad social ascendente en Argentina, y la irrupción de movimientos como el anarquismo y el socialismo, que amenazan la legitimidad del orden oligárquico.

57 A pesar de estos límites, Girgois se desvía en varios aspectos respecto de los discursos hegemónicos. Entre otros rasgos, si bien retoma la perspectiva "andinocéntrica" dominante, también reconoce la importancia cultural de los araucanos y de los guaraníes, e incluso -contradiciendo su propio involucramiento en la "Campaña al Desierto"-, denuncia abiertamente los abusos cometidos en el pasado y en el presente contra los indígenas, en nombre de la civilización. 


\section{continuar luego resonando}

-con variantes- en el indianismo espiritualista de los años veinte y treinta, en obras como la de Rojas, consolidándose así una tradición discursiva que insiste en defender los tópicos propios del indianismo esotérico, para sostener una legitimación simbólica del mundo indígena, aun cuando avanza la antropología científica, consolidándose precisamente contra este tipo de especulaciones "fabulosas".

\section{BIBLIOGRAPHY}

Angenot, M. (2010). El discurso social. Buenos Aires: Siglo XXI.

Ennis, J. (2018). Las novedosas ciencias del lenguaje y la política de sus usos: Vicente Fidel López en la Revista de Buenos Aires. Boletín de la Sociedad Española de Historiografía Lingüística, 12.

Ennis, J. (2019). Cuestión de matices: el idioma de los argentinos, su ciencia y sus ancestros. El taco en la brea, VI (10). 
Errington, J. (2008). Lingüistics in a Colonial World. Oxford: Blackwell.

Faivre, A. (1994). Access to Western Esotericism. Albany: State University of New York Press.

Fontana, L. J. (2009 [1881]). El Gran Chaco. Formosa. Ministerio de Cultura y Educación de la Provincia de Formosa.

Gauchet, M. (2000). El verdadero Charcot. Buenos Aires: Nueva Visión.

Girgois, H. (1897). L'occulte chez les aborigènes de l'Amerique du Sud. París: Chamuel.

Girgois, H. (1901). El oculto entre los aborígenes de la América del Sud. Los quechuas, raza ariana. Barcelona: Torrents y Coral.

Gorleri, M. E., Budiño, M. y Renzulli, M. (2020). Representar la frontera: Formosa, 1879-1950. Subjetividades, identidades y territorio. Formosa: EdUNaF.

Imbelloni, J. (1920). Dos americanismos. Boletín del Instituto de Investigaciones Históricas. Buenos Aires: Peuser.

Imbelloni, J. (1926). La esfinge indiana. Buenos Aires: El Ateneo.

Imbelloni (11/02/1926). Cinco misterios convencionales de Tiahuanaco. La Prensa, Buenos Aires. Imbelloni, J. (1936). Humanior. Biblioteca del Americanista moderno. Introducción general. Buenos Aires: José Anesi.

Imbelloni, J. y Vivante, A. (1939). Libro de las Atlántidas. Buenos Aires: José Anesi/Biblioteca Humanior.

Imbelloni, J. (1942). La Weltanschauung de los Amautas reconstruida: formas peruanas del pensamiento templario. (folleto). Actas del Congreso Internacional de Americanistas. Buenos Aires: Museo Argentino de Ciencias Naturales.

Imbelloni, J. (1947). La formación racial argentina. En AA.VV. Argentina en marcha. Buenos Aires: Comisión Nacional de Cooperación Intelectual.

Lázari, A. (2002). Indio argentino, cultura nacional. En Visakovsky, S. y R. Guber (Comps.). Historia y estilos de trabajo de campo en Argentina. Buenos Aires: Antropofagia.

Lázzari, A. (2004). Antropología en el Estado: el Instituto Étnico Nacional (1946-1955). En F.

Neiburg y M. Plotkin (Comps.). Intelectuales y expertos. La constitución del conocimiento social en la Argentina. Buenos Aires: Paidós.

López, V. F. (1871). Les races aryennes du Pérou. Leur langue. Leur religion. Leur histoire. París: Franck.

Mailhe, A. (2009). Hacer el desierto. Ensayo y fotografía en la percepción del "otro" durante la “Campaña al Desierto”. Representaciones. V (2).

Mailhe, A. (2013). "El laberinto de la soledad" del genio o las paradojas de El hombre mediocre. Vária História, 29 (49).

Mailhe, A. (2016). Archivos de psiquiatría y criminología (1902-1912): concepciones del sujeto femenino y de la alteridad social. Biblioteca Orbis Tertius. La Plata: FAHCE. Disponible en: bibliotecaorbistertius.fahce.unlp.edu.ar

Mailhe, A. (2017). Creencias y supersticiones en conflicto: visiones de la religiosidad popular en el positivismo argentino de entresiglos. Orbis Tertius, ${ }^{\circ} 26$.

Mailhe, A. (2018a). La colección "Humanior" y la formación de un lectorado americanista. Prismas, $\mathrm{n}^{\circ} 22$. 
Mailhe, A. (2018b). El mestizaje indo-hispánico en la educación estética de las masas. Estudios del ISHIR, 22

Mailhe, A. (2020a). El impacto de La decadencia de Occidente de Oswald Spengler en los indigenismos latinoamericanos: el caso de Ernesto Quesada. En P. Arenas y L. Dávila (Comps.), El americanismo germano en la antropología argentina de fines del siglo XIX al siglo XX. Buenos Aires: CICCUS/CLACSO (en prensa).

Mailhe, A. (2020b). ¿Legados prestigiosos? La revalorización del sustrato cultural indígena en la construcción identitaria argentina, entre fines del siglo XIX y los años treinta. Estudios sociales del NOA, 23 (en prensa).

Martius, K. V. (1982 [1823]). O estado de direito entre os autóctones do Brasil. San Pablo: Itatiaia.

Mitre, B. (1954 [1879]). Las ruinas de Tiahuanaco. Buenos Aires: Hachette.

Mitre, B. (2015 [1888]). “Carta-prólogo” a González, Joaquín V. La tradición nacional. Buenos Aires: Unipe.

Quesada, E. (1926). Spengler en el movimiento intelectual contemporáneo. Humanidades. La Plata: Universidad Nacional de La Plata.

Quijada, M. (1996). “Los incas arios”. Historia, lengua y raza en la construcción nacional hispanoamericana del siglo XIX. Histórica, XX (2).

Quiroga, A. (1942 [1901]). La cruz en América. Buenos Aires: Americana.

Rojas, R. (1951 [1922]). Eurindia. Ensayo de estética sobre las culturas americanas. Buenos Aires: Losada.

Rojas, R. (1930). Silabario de la decoración americana. Buenos Aires: La Facultad.

Schuré, E. (1921 (1889]). Les Grands Initiés. París: Librairie Acadêmique.

Tenorio Trillo, M. (1990). Bartolomé Mitre y Vicente Fidel López: el pensamiento historiográfico argentino en el siglo XIX. Secuencia, 16.

Toffoli de Matheos, M. (1982). Las primeras farmacias en La Plata. Acta farmacéutica bonaerense, 2.

Villalba, M. (2018/2019). Arnold Krumm Heller, la Revolución Mexicana y el esoterismo en América Latina. REHMLAC, 10, (2).

Villalba, M. (2021). The Occult Among the Aborigines of South America? Some Remarks on Race, Coloniality, and the West in the Study of Esotericism. En E. Asprem y J. Strube (Comps.), New Approaches to the Study of Esotericism. Leiden and Boston: Brill (en prensa).

\section{NOTES}

1. Tanto las hipótesis temerarias del libro, como el carácter multidisciplinar del mismo, e incluso la gravitación muy débil del indianismo romántico local, pueden haber colaborado en la poca atención prestada a esta fuente por parte de la crítica académica, hasta lecturas más recientes como la de Quijada (1996) o de Ennis (2018 y 2019).

2. Así por ejemplo, varias tesis expuestas en el "Primer Congreso de Americanistas" celebrado en 1875, poco después de la edición de Les races aryennes..., vuelven sobre estas especulaciones. Al respecto, ver Quijada (1996).

3. Quijada (1996) recuerda que Müller usa esta última noción, como sinónimo de "indoeuropeo", en las conferencias dadas en Oxford entre 1861 y 1863. Ennis (2018) agrega que el término "ario", 
como sinónimo de "indoeuropeo", se vuelve común en los trabajos de lingüística y de humanidades en el mundo anglosajón de esta etapa.

4. Tal como advierte Ennis (2018), las tesis de Müller, centradas en lo que define como lenguas “indoeuropeas", consolidan la filología comparada, jugando indirectamente un papel clave en la expansión del imperialismo europeo. Su perspectiva impacta en el Río de La Plata, no solo en Vicente Fidel López sino también en Juan María Gutiérrez, basándose ambos en el comparatismo de Müller para relegitimar las lenguas indígenas.

5. Combinando estudios filológicos y colonialismo (como representante de la British East India Company), el orientalista británico William Jones estudia, a fines del siglo XVIII, las semejanzas entre el sánscrito, el griego y el latín por un lado, y las lenguas de la Europa moderna por otro, remontándose así a una lengua proto-indoeuropea, tronco común del que se habrían desprendido el sánscrito, el griego, el latín, el germánico y el céltico (entre otras lenguas), en base a desplazamientos en el espacio a lo largo de la historia. Poco después, el alemán Friedrich Schlegel publica Über die Sprache und Weisheit der Inder (1808; Sobre la lengua y la sabiduría de los hindúes), donde recupera las ideas de Jones y sostiene el parentesco común entre estas lenguas y la mayor antigüedad del sánscrito; además allí introduce la novedad de proponer un modelo comparativo ya no basado en las formas léxicas, sino en la gramática; de ubicar las lenguas americanas evolutivamente por debajo de las flexivas, y de sugerir algunas posibles correspondencias entre el diccionario peruano y el sánscrito, en base a alguna forma de migración o contacto entre el mundo andino y Oriente.

6. Sobre la importancia de la filología en la justificación del colonialismo europeo, ver Errington (2008).

7. Desde Oxford, Müller difunde sus tesis en inglés y en francés, con gran éxito en Europa y en América, a lo largo de todo el siglo XIX. Realizando una síntesis teórica de la lingüística comparada, Müller divide las lenguas en tres tipos: las aislantes (como el chino), donde todas las palabras son raíz; las turánicas o aglutinantes (como el turco, el mongol y el quichua), con afijos que no modifican la raíz, y las flexivas (como las indoeuropeas y las semíticas), donde los afijos modifican la raíz. Pensada en el marco de una jerarquía eurocéntrica ascendente, Schlegel considera que solo las lenguas flexivas permiten expresar conceptos complejos. Müller le agrega a este esquema jerárquico una asociación entre tipo de lengua y tipo de estructura social, advirtiendo que las lenguas aglutinantes corresponden a una fase nómade de desarrollo, mientras que las flexivas se despliegan en sociedades civilizadas.

8. Quijada (1996) advierte que, en Argentina, la obra de López tuvo poco impacto, entre otras razones por la oposición férrea de Bartolomé Mitre, quien en dos notas marginales, que constan en su ejemplar de Les races aryennes..., condena taxativamente la hipótesis de la capacidad de progreso, y del desarrollo lingüístico del pensamiento abstracto, entre los incas. El libro de López impacta en cambio positivamente en Juan María Gutiérrez, así como también en el peruano José Fernández Nodal, el mexicano Gumesindo Mendoza (quien, partiendo explícitamente de López, busca demostrar las correspondencias entre las lenguas indoeuropeas y el náhuatl), y el brasileño José Couto de Magalhães, que en 0 selvagem (1876) adapta la tesis de López para legitimar a los indígenas brasileños, confiando en el encuentro futuro de alguna gran civilización en las selvas amazónicas, comparable a las del mundo andino.

9. Así por ejemplo, la segunda edición del ensayo La tradición nacional de Joaquín V. González incluye una carta-prólogo de Bartolomé Mitre en la que este impugna abiertamente la idea de que los hispanoamericanos puedan descender de los indios. Para Mitre, acontecimientos como la exitosa represión de la rebelión de Tupac Amaru demuestran el "triunfo natural" de la América civilizada, que "no se proponía ni continuar a los indios ni restaurar el Imperio americano" (González, 2015, p. 296), sino recrear a Europa en América. Además, en 1879, precisamente el año en que se cierra oficialmente la llamada "Campaña al Desierto", Mitre edita Las ruinas de Tiahuanaco, explayándose sobre las antiguas civilizaciones del mundo andino y sobre las 
poblaciones indígenas contemporáneas, a partir del viaje realizado a este yacimiento arqueológico. Allí Mitre repite varios tópicos heredados de las elucubraciones coloniales y románticas sobre Tiahuanaco, que desde la década del diez serán centrales en la interpretación que consolida el arqueólogo austríaco Arthur Posnansky, que a su vez impactan en las obras de Rojas. Así por ejemplo, Mitre elogia la monumentalidad y la riqueza de las imágenes grabadas en las ruinas, comparándolas con los bajorrelieves griegos, egipcios y aztecas; se deja fascinar por sus “murallas ciclópeas" y "sus estatuas colosales" (Mitre, 1954, p. 103), así como también por la complejidad de sus símbolos, aun mal descifrados; considera que esa civilización es previa y superior respecto de la incaica; especula acerca de su posible organización teocrática; advierte que, para cuando arribaron los conquistadores, en la región solo quedaban semi-civilizaciones en decadencia, contrastantes con respecto al esplendor de Tiahuanaco, y traza una visión muy negativa acerca de los indios del área en el presente, aunque reconoce la perduración de algunas habilidades específicas, racialmente heredadas de aquellos tiempos gloriosos. Además, en sintonía con varios discursos románticos previos, invisibiliza las experiencias brutales de la conquista y de la explotación colonial, advirtiendo -como luego lo hará Posnansky- un retroceso civilizatorio por "cataclismos sociales" (como la invasión de otros grupos indígenas menos cultos, que se habrían impuesto por la fuerza),/o por "causas ingénitas" como las propias cualidades biológicas de los indios, que dificultan el progreso (Mitre, 1954, p. 194).

10. En 1881 López mantiene un célebre debate con Bartolomé Mitre sobre la historia argentina, a partir de la edición de la Historia de Belgrano por parte de Mitre. López publica dos volúmenes, Debate histórico. Refutaciones a las comprobaciones históricas sobre la historia de Belgrano, en 1881, para refutar la perspectiva de Mitre. El fondo del conflicto radica en una concepción opuesta respecto de la tarea historiográfica (fuertemente documentada como historiografía "científica", desde la óptica de Mitre, y más bien ensayístico-filosófica, desde la perspectiva "literaria" de López). Al respecto ver Tenorio Trillo (1990).

11. En la edición en español, se expande significativamente la información sobre araucanos y guaraníes, como resultado probablemente del estudio de Girgois (que se traduce en una importante ampliación del conocimiento etnográfico) y del mayor interés por esos grupos por parte del lectorado local (en contraste con el público francés, limitado al más famoso legado andino). Sin embargo, la información incorporada en la edición en español es despareja, revelando las limitaciones de Girgois para abordar en detalle diversos temas en esos grupos (por ejemplo, cuando analiza lo oculto entre los guaraníes, cita como fuente principal un fragmento del poema histórico La Argentina de Martín del Barco Centenera, de 1602).

12. La Orden Martinista tradicional es creada en 1890 por Gérard Encausse (médico y ocultista francés), para transmitir la doctrina de Martínez de Pasqually y de Louis Claude de Saint Martin (de donde deriva el término "martinismo"). Vinculado inicialmente a la Sociedad Teosófica fundada por Blavatsky, Papus se aparta al rechazar el énfasis dado por esta última a Oriente, y en 1888 funda su propio grupo, más europeo y cristiano, generando así su propia versión de una Teosofía "a la francesa", bajo el nombre de "Orden cabalística de la Rosacruz". Además, Papus organiza el "Grupo independiente de estudios esotéricos" o "Ecole Hermetique", que por entonces difunde el conocimiento de la Cábala y de las ciencias herméticas, entre otros saberes. 13. Al respecto, ver por ejemplo Villalba (2018/2019 y 2021), uno de los poquísimos autores estudioso de la figura de Girgois. Parte de la información de Villalba proviene de haber revisado un archivo en Lyon que contiene los manuscritos de Papus. Vale la pena recordar, además, que a fines del siglo XIX, Girgois se desempeña como farmacéutico en su "Botica y Droguería del Indio", ubicada en La Plata (en la cual probablemente aplica parte de sus conocimientos sobre la farmacopea amerindia). Además de identificar dicha botica en La Plata (en dos direcciones diferentes, por una mudanza ocurrida entre 1883 y 1884), Toffoli de Matheos (1982) señala que, en 1884, Girgois es designado embalsamador y conservador en el Museo de Ciencias Naturales de La Plata, situación que quizás haya suscitado el intercambio de ideas con otros intelectuales 
vinculados al Museo, y quizá también con algunos indígenas sobrevivientes de la "Campaña", trasladados a dicha institución. Por otro lado, como prueba de la continuidad de la corriente martinista en Argentina, cabe señalar que, varios años después de la publicación del libro de Girgois, el artista plástico Xul Solar da cursos de astrología en la misma escuela fundada en Buenos Aires por el autor de El oculto..., y pone parte de su talento estético al servicio de esa institución.

14. Para demostrar el origen oriental de los quichuas, cita antiguas leyendas chinas y quichuas, que refieren viajes desde Oriente hasta Sudamérica, y diversos artículos contemporáneos editados en periódicos (como una nota aparecida en el Colombian Herald, que narra el descubrimiento en Colombia de antiguas monedas chinas, de 3.000 años de antigüedad, como prueba del contacto de China con Sudamérica en el marco del poblamiento de este continente). Girgois también recuerda que, para el cronista colonial Fernando de Montesinos, las primeras tribus salieron de Armenia en el 500 después del diluvio universal, para llegar a Perú. Con respecto a la bibliografía en la cual se basa, luego del prólogo Girgois introduce una lista de autores que incluye desde cronistas coloniales hasta viajeros europeos y exploradores americanos más contemporáneos (citados en función de los tres grandes grupos estudiados: quichuas, araucanos y guaraníes); sin embargo, la apelación a esas figuras de autoridad es asistemática, y gran parte de la información etnográfica es presentada en el ensayo sin remitir a fuentes específicas.

15. Girgois dice tener frente a sí un diccionario quichua con equivalentes en sánscrito (el cual no cita), en donde más del $80 \%$ de los términos deja entrever el origen ario del que la lengua quichua se habría desprendido hace más de 1.000 siglos.

16. Ver el apoyo en la fuente de López, por ejemplo en Girgois (1901, p. 56).

17. Así por ejemplo, cuando aborda el culto de la luna menguante, señala que entre los tiahuanacotas es ka ata killa ("resplandor engañador"), semejante a ate y a Hécate en griego (símbolo de la luna menguante), y próximo a ator entre los egipcios, con el mismo sentido de anticipación de la brujería que entre los indios, porque todos los casos se desprenden de at, que en las lenguas "arianas" alude al mismo misterio. Si rumi es "piedra" en quichua (un término próximo a roma, que entre griegos y romanos remite a la solidez de la piedra), Tiahuanaco parece edificada por un arquitecto romano, por la semejanza con la que, en ambas culturas, se construyeron las murallas de piedra. Cuando describe los templos de Tiahuanaco, basándose en las Crónicas peruanas de Cieza de León, advierte que los antiguos peruanos crearon templos semejantes a los de la India, excavados en las montañas, o que el empleo de una varilla para la adivinación no casualmente es un recurso común entre los quichuas y los hindúes (Girgois, 1901, p. 283). También señala que el culto a los aerolitos es practicado por quichuas y romanos, o que la serpiente que se muerde la cola es un símbolo común entre quichuas y pelasgos (Girgois, 1901, p. 241), probando así la "similitud en las creencias, usos y costumbres entre los arianos del Viejo Continente y los quichuas" (Girgois, 1901, p. 228).

18. Su pulsión nacionalista se hace evidente por ejemplo cuando, apelando a un argumento heredado de López, recomienda su libro "a los amantes de las cosas de la patria argentina, porque si bien se trata del Perú, sabido es que todas las provincias andinas de la Argentina pertenecían al imperio de los Incas" (Girgois, 1901, p. 76), dando como prueba la perduración del quichua en varias regiones del país.

19. Faivre (1994) propone un modelo sistemático para definir el esoterismo como una forma de pensamiento, identificable por medio de cuatro características fundamentales, presentes en un amplio conjunto de corrientes (y a las que suma la creencia en una Prisca Theologia común): la teoría de las correspondencias (concepción acerca de la existencia de relaciones reales y simbólicas entre todas las partes del universo visible e invisible -entre microcosmos y macrocosmos-, de tal modo que el universo constituye un inmenso teatro de espejos); la idea de una naturaleza viviente (pues el cosmos es percibido como complejo, plural, jerarquizado, y la 
naturaleza como esencialmente viva en todos sus componentes, e impregnada de un principio vital o luz astral que sirve como soporte para las operaciones mágicas; la magia es el conocimiento de las redes de "simpatías" y "antipatías" que unen las cosas de la naturaleza); la mediación (a través de rituales, imágenes simbólicas, mandalas, ángeles, espíritus intermediarios, para desarrollar un conocimiento que permite develar los secretos de la naturaleza, poner en práctica la teoría de las correspondencias, y conocer a las entidades mediadoras entre la naturaleza y el mundo divino), y la experiencia de la transmutación (para actuar sobre las fuerzas de la naturaleza mediante una metamorfosis, como pasaje de un "plano de realidad" a otro, incluyendo la modificación del sujeto en su propia naturaleza). Asimismo, el esoterismo tiende a sostener la enseñanza secreta a través de un maestro que confiere la iniciación en los misterios a sus discípulos.

20. En efecto, la búsqueda de esta compatibilidad esotérica no es nueva en la historia latinoamericana. De hecho, tal como recuerda Villalba (2021), luego de la Conquista algunos indígenas mestizados, como el Inca Garcilaso de la Vega, se apropian del hermetismo renacentista para legitimar las tradiciones precolombinas, generalmente consideradas como idolatría, y de este modo ganarse un lugar en la historiografía cristiana. Para ello, suelen buscar apoyo en la -arriba mencionada- Prisca Theologia, doctrina renacentista vinculada al neoplatonismo y al hermetismo, surgida con Ficino y Pico della Mirandola. Prolongando ese tipo de sincretismos en un nuevo contexto enunciativo, Girgois (al igual que su sucesor, Krumm Heller) busca conciliar los mitos precolombinos con el esoterismo moderno, inspirándose en el anhelo por recuperar formas originales del misticismo y la magia, consideradas como equivalentes -e incluso como más puras- que las formas europeas contemporáneas.

21. Así por ejemplo, Girgois advierte la profunda elaboración metafísica implícita en el pensamiento quichua, que en su evolución llega a concebir un espíritu puro, independiente respecto de la materia, a través de la figura de Huiracocha, frente a cuya representación el pueblo progresa al punto de superar el mero fetichismo (Girgois, 1901, p. 85). Y frente a los cultos quichuas al sol, la luna, las montañas, los dioses tutelares de la familia o los muertos (incluyendo la creencia en la resurrección y en la reencarnación), Girgois subraya no solo las correspondencias (de nombres y de contenido) con divinidades egipcias, griegas, etruscas e hindúes, sino también la convergencia con los esoterismos contemporáneos (por ejemplo, entre la creencia quichua en la separación del alma y el cuerpo en el sueño, y los viajes astrales "en algunas escuelas espiritualistas actuales"; Girgois 1901, p. 101).

22. Aunque sí reconoce la sacralidad del número cuatro entre los quichuas (visible -entre otros elementos- en que el mundo está dividido en cuatro partes; la sociedad está organizada en cuatro castas, y se celebran cuatro fiestas al año).

23. Así por ejemplo, subraya el origen quichua de términos mapuche como "Patagonia", que provendría del quichua "Patak Humía”, “tierra de montañas” (Girgois, 1901, p. 125). También advierte entre los guaraníes algunas correspondencias con las creencias de los incas (como el culto a la luna), que pueden haberse originado por el contacto con este grupo, aunque insiste en que los guaraníes no alcanzaron el grado de elaboración cultural al que sí llegó el mundo andino.

24. Para sostener esta hipótesis, acumula diversos argumentos, dejando entrever una competencia por el mayor prestigio simbólico del legado incaico. Apelando a argumentos prácticos (por ejemplo, sobre el desplazamiento por mar, más fácil del sur al norte que al revés, dada la dirección de las corrientes marinas), y a argumentos filológicos (como el nombre dado a la región por los primeros migrantes, como "peru", que en sánscrito significa "oriente"), Girgois sostiene que el inglés "Fergussón"(sic), al comparar la arquitectura peruana con la mexicana, subraya que la primera es claramente superior, y solo "comparable a las murallas ciclópeas y pelásgicas del Latium” (Girgois, 1901, p. 30). Lo mismo ocurriría con la cerámica peruana, más refinada que la tolteca y afín en cambio a la egipcia, la etrusca y la pelásgica, tal como habrían demostrado Mariano Rivero y Johann Tschudi en sus Antigüedades peruanas (1851). 
25. Así por ejemplo, apoyándose en D’Orbigni y en James Prichard, advierte que los quichuas "son esencialmente diferentes de las demás razas americanas" desde el punto de vista físico y psicológico, pues tanto su color de piel como su perfil ("que forma un ángulo obtuso casi igual al de los europeos", Girgois, 1901, p. 26), e incluso sus cualidades morales, contrastan con las de las demás razas del continente. Esa asimetría (biológica, moral y cultural) se potencia con el mayor desconocimiento etnográfico sobre el grupo guaraní. Precisamente en el momento en que se desarrolla la campaña militar de "pacificación" del Gran Chaco, Girgois señala que los guaraníes no tuvieron condiciones materiales ni intelectuales como para desarrollar una cultura compleja como la de los quichuas, y se recluyeron en el Chaco para resistir la dominación colonial, conservando hoy la misma independencia (y el mismo sustrato cultural) de hace tres siglos.

26. La certeza sobre la decadencia de los indígenas, en el pensamiento romántico, puede rastrearse por ejemplo en el ensayo $O$ estado de direito entre os autóctones do Brasil (1823) del naturalista alemán Karl F. P. Martius, dedicado al estudio de los indígenas amazónicos. El mismo tópico, con variantes (dado el cambio evidente del contexto enunciativo), puede encontrarse en "La formación racial argentina" (1947) de José Imbelloni.

27. Si bien excede los objetivos de este trabajo, podría confrontarse la perspectiva de Girgois con la de intelectuales contemporáneos, vinculados a las campañas militares a la Patagonia y al Gran Chaco, como en el caso de Estanislao Zeballos en Viaje al país de los araucanos (1881), o en el de Luis Jorge Fontana en El Gran Chaco (1881). Ambos autores evalúan de manera distante y preconceptuosa a los grupos indígenas de las regiones respectivamente exploradas, asumiendo un punto de vista miserabilista y bestializador, dominante en el período, que completa el ejercicio represivo desplegado por las campañas militares. Sobre Zeballos ver Mailhe (2009); sobre Fontana ver Gorleri, Budiño y Renzulli (2020).

28. Como en el caso del español Daniel Granada, dedicado al tema de las supersticiones en el Río de la Plata. Sobre las contradicciones ideológicas de Granada ver Mailhe (2017).

29. En efecto, Ferdinand de Lahille (que había sido contratado en 1893 en Francia, para estudiar la fauna de las costas de la Argentina) forma parte de la "Sección de exploraciones nacionales" del Museo de Ciencias Naturales de La Plata, y en ese contexto viaja a Tierra del Fuego en 1896, para estudiar los recursos naturales de esa región. Ayudado por algunos indios que hablan algo de español, y por el jefe de policía del territorio -tal como él mismo reconoce-, aprende algunos rudimentos de la lengua y de la cultura de los selk'nam, vinculándose especialmente con el chamán Tenenésk, mestizo de madre haush y de padre selk'nam. A partir de esa experiencia produce algunos textos (como el ensayo "Materiaux pour servir a l'histoire des Oonas", publicado recién en 1926), en los que insiste en la hipótesis del prestigioso origen de los selk’nam, en base a una antigua cultura madre, compartida con los griegos y con otras civilizaciones antiguas como las de Siam y Java. Como López y Girgois -ambos, como vimos, bajo la influencia de Müller-, Lahille apela a la filología y a la mitología como las canteras que atesoran las huellas de ese pasado común.

30. Al subrayar la formación y el entrenamiento médico entre los indios, se detiene (con un detalle y una admiración notables para la época) en el caso de las machis, reseñando su educación desde la infancia, marcada por el estudio de las plantas, el respeto por la castidad, el aprendizaje de la sugestión hipnótica como instrumento de cura y el entrenamiento en resistir la propia sugestión, entre otros rasgos.

31. En efecto, en un gesto rupturista para la época, hace explícita su consciencia respecto de la incomodidad que supone el empleo de términos como "brujo", cargados de connotaciones negativas (Girgois, 1901, p. 286), esforzándose en cambio por preservar la terminología chamánica de cada grupo indígena.

32. Sobre la persecución de estas prácticas en la Argentina de entresiglos, ver por ejemplo Mailhe (2017). 
33. Así por ejemplo, frente al arrojo de las machis ante un brote de viruela durante la "Campaña", sentencia que "estos seres desgraciados, arrancados de sus tolderías en nombre de la civilización, despojados de todo, apenas abrigados por miserables andrajos, restos sin valor de la codicia de los soldados, se mostraron llenos de abnegación..." (Girgois, 1901, p. 153).

34. A quien cita (Girgois, 1901, p. 334), para defender la importancia del quichua para la civilización de las naciones sudamericanas.

35. Lo mismo sucede en los funerales araucanos, marcados por el consumo del alcohol (aunque reconoce que se trata de un vicio civilizatorio). Este tipo de prácticas más "salvajes" establecen un claro contrapunto con respecto al misticismo "elevado" de las ceremonias quechuas del pasado, de tal modo que la condena se subraya sobre todo en relación a la decadencia de los indígenas en el presente.

36. A la ductilidad de la lengua quichua para dar cuenta de un estadío superior de civilización se suman el desarrollo de saberes "civilizados", así como también la elaboración de un sistema de producción agrario ideal, basado en el reparto solidario de las cosechas, gracias a la intervención del Estado, a tal punto que resulta "difícil imaginarse una ley agraria más completa y más verdadera" (Girgois, 1901, p. 36), una división social armónica del trabajo (entre elite dirigente, curacas, soldados y pueblo; Girgois, 1901, p. 81), y la elaboración de una religión "pura y elevada", marcada por una alta concepción moral difundida entre la población por los sacerdotes (al punto de alcanzar la superioridad moral con respecto al hombre europeo), mientras una nobleza valiente e ilustrada gobierna sobre un pueblo "inteligente, laborioso, dócil" (Girgois, 1901, p. 38; bastardilla nuestra).

37. Aunque excede los objetivos de este trabajo, vale la pena señalar que, en este punto, sería posible comparar la idealización de la armonía comunitaria en el mundo precolombino, por parte de Girgois, con la idealización de la misma armonía en el mundo colonial, por parte de Adán Quiroga, en Folclore calchaquí (1897). Aunque retornan a pasados diversos, en ambos autores anida la misma nostalgia por la comunitas perdida.

38. Entre los quichuas prehispánicos, si las clases superiores (de huilkas y amautas) son monoteístas, el pueblo no logra superar el politeísmo, recreando a su modo "las emanaciones de la divinidad suprema" (Girgois, 1901, p. 114), lo cual resulta aceptable de acuerdo a su grado de desarrollo intelectual. Con esfuerzo, el vulgo tiende a alcanzar un espiritualismo dualista como meta, llegando incluso a representar el sol como Dios supremo, dado que el punto máximo "de desarrollo intelectual y científico" supone la representación de principios y ya no de dioses (Girgois, 1901, p. 122). Por eso Girgois advierte que los etnógrafos, como los antiguos cronistas, se equivocan cuando creen que los indios son meros adoradores del sol o de la luna: no pueden reconocer que, en realidad, ese culto popular es una adaptación del culto a principios abstractos, ya alcanzado por los grupos más desarrollados dentro de la misma comunidad (en este sentido, el sol encarna una manifestación sensible del Bien, asequible por parte del vulgo).

39. Tal es el caso, por ejemplo, de la achura, una planta alucinógena difundida en las prácticas adivinatorias entre los quichuas, cuyo nombre científico no quiere divulgar por ser "uno de los más violentos venenos" (Girgois, 1901, p. 232)

40. Sobre el elitismo implícito en El hombre mediocre ver Mailhe (2013).

41. Al respecto ver Mailhe (2016).

42. Sobre la reformulación de la sugestión hipnótica en Charcot ver Gauchet (2000). Sobre la expansión de las tesis de Charcot en Argentina, por ejemplo en la obra de José Ingenieros, ver Mailhe (2016).

43. Sobre este punto en Imbelloni ver Mailhe (2018a).

44. Imbelloni (1920, p. 23).

45. Entre 1921 y 1928, Leo Frobenius publica los doce volúmenes de Atlantis (Jena, Diederichs, 1921-1928). Enfatizando esa proximidad teórica con Frobenius, todo el cierre del Libro de las Atlántidas se centra en la arqueología de este autor, compartiendo su hipótesis de una elevada 
civilización en África, resultado de la difusión "de la joven cultura helénica" en fusión con una cultura más antigua, proveniente del Asia menor, en un ciclo que Frobenius define como cultura "malayo-negroide".

46. Ver por ejemplo Imbelloni (11/02/1926).

47. Con respecto al escenario americano, señala que "si una literatura en parte romántica y en parte periodística lo ha sostenido en las esferas subalternas de la publicidad, hoy día, después de varias décadas de educación antropológica intensiva, todos ven que no es ya tolerable la idea de la existencia de islas encantadas y regiones misteriosas. La razón verdadera es que el hombre de África, de Asia meridional y de Oceanía ha sido investigado en una época relativamente moderna [...] en la atmósfera de las ciencias. La literatura americanista -en cambio- que tenía ya en 1607 la exuberancia de una selva tropical, se formó cuando solo la Guinea africana y pocas otras costas fuera de Europa eran familiares al blanco y jamás, ni en nuestros días, ha logrado desprenderse de la ingenua maravilla con que el siglo XV acogió la primera masa humana [americana]. Junto con tal maravilla iban unidos gran número de mitos cosmográficos, raciales y etnológicos que todavía no están del todo desarraigados, aunque el mayor obstáculo para la comprensión de América consiste en la presunción de su aislamiento y singularidad" (Imbelloni, 1953, p. 9; bastardilla nuestra).

48. La respuesta de Imbelloni se encuentra en sintonía con los planteos del Instituto Étnico Nacional, que funciona en Argentina entre 1946 y 1955. Buscando intervenir en el mejoramiento físico y moral de la población, promueve una inmigración selectiva, para no poner en riesgo la identidad étnica nacional. En esta dirección, Santiago Peralta, a cargo de este Instituto, apoya la inmigración europea de latinos católicos, y el confinamiento tutelado de los indígenas como fuerza productiva (ver Lázzari, 2004). Imbelloni converge en términos generales con el enfoque de Peralta, aunque

-según advierte Lázzari- también cuestiona el perfil poco académico de este último.

49. Si bien el tema excede los objetivos de este artículo, cabe destacar que, por ejemplo, el Instituto Nacional de la Tradición define lo indígena como un elemento menor, asimilado (aunque no sin conflictos) a lo criollo, en oposición simbólica a la inmigración y al liberalismo. Esta perspectiva presenta entonces una parcial disidencia con respecto al enfoque inmigracionista de Imbelloni (ver Lázzari, 2002).

50. Ese gesto de legitimación parcial anticipa, al menos en parte, la corrección teórica que, en los años veinte, lleva a cabo el sociólogo argentino Ernesto Quesada frente a la tesis de Oswald Spengler, cuando (en textos tales como "Spengler en el movimiento intelectual contemporáneo", de 1926) le advierte al filósofo alemán sobre el advenimiento inminente de un nuevo ciclo cultural americano, de base indígena (en desmedro de la hipótesis del propio Spengler, sobre un renacimiento soviético, activado por la Revolución). Sobre este tema ver Mailhe (2020a).

51. En efecto, Rojas no cita a Girgois, aunque las fuentes esotéricas que gravitan en Eurindia (1922), y sobre todo en el Silabario de la decoración americana (1930) aproximan fuertemente su escritura respecto de El oculto..., para pensar

-en ambos casos- el alto valor del misticismo indígena. Interviniendo en contextos históricos diversos (dada la distancia de casi 30 años que separa la edición de El oculto... respecto del Silabario...) en los que mudan las condiciones de posibilidad del indianismo argentino (más sólido desde los años veinte, gracias al despliegue de los primitivismos de posguerra), cada uno asume posiciones diversas dentro del campo intelectual nacional (pues la marginalidad de Girgois apenas reconocido en el ámbito del esoterismo local- contrasta con la consagración de Rojas como Maestro del reformismo y como americanista, con una clara relevancia nacional y continental). A pesar de estas diferencias, ambos autores advierten la naturaleza humana universal que se palpa en las obras prehispánicas y en las creencias y mitos indígenas contemporáneos. Si bien Girgois enfatiza la universalidad de los conocimientos esotéricos, y Rojas más bien la universalidad de la experiencia estética, en ambos anida la fascinación por el misticismo indígena. El esoterismo moderno en el caso de Girgois, y el arte -cargado de 
misticismo- en el caso de Rojas, deben aspirar a forjar una integración armónica, euríndica, que suture las diferencias culturales, e incluso las diferencias de clase. En última instancia, desde una posición esotérica próxima, en los dos autores se manifiesta la misma nostalgia por la comunitas perdida o en proceso de disolución por el avance de la Modernidad.

52. En efecto, Rojas se basa, entre otros textos, en Les Grands Initiés (1889) de Edouard Schuré. Varios libros de este autor se encuentran en la biblioteca personal de Rojas, conservada en la Casa Museo, incluso con indicaciones marginales que confirman esta hipótesis.

53. Luego en su Silabario..., Rojas parte explícitamente de La doctrina secreta de Mme. de Blavatsky -entre otros autores-, para redoblar su apuesta en favor de recuperar la espiritualidad indígena como fuente de inspiración estética, apostando por la hipótesis de una cultura madre común para todo el mundo precolombino, como deriva probable de la Atlántida perdida, a través de la cual América restablece su vínculo con Europa y con Oriente. Y al igual que Girgois, no solo apela a la hipótesis histórica de una migración remota, sino también a la manifestación compartida de un mismo conocimiento esotérico universal pues, recreando las síntesis dialécticas tan caras al modelo euríndico, Rojas avanza en su ascensión universalizante, al postular no solo la unidad americana por la vía de la espiritualidad precolombina, sino también la existencia de una unidad más vasta, "por las reminiscencias de una simbología universal que, bajo las mismas o parecidas formas, aparece en algunos pueblos precolombianos y que es común a todas las religiones" (Rojas, 1930: 113). Al respecto ver Mailhe (2018b).

\section{ABSTRACTS}

This work explores the imaginary gravitation of the Orient and Antiquity in some visions about the Andean world, produced between the end of the $19^{\text {th }}$ century and the beginnings of the $20^{\text {th }}$ century. It analyses the connections established by some intellectuals between the indigenous heritage and the "Indo-European" past, firstly in the generation of romantic Indianists, then in authors related to spiritualism at the turn of $20^{\text {th }}$ century, and finally during the crisis that followed the First World War. In Argentina, authors such as Vicente Fidel López and Henri Girgois highlight the links between the Andean world and the Orient, based on remote cultural contacts and similar manners to conceptualize the world. Starting from Les races aryennes du Pérou (1871) by Vicente Fidel López, this article particularly dwells on the essay El oculto entre los aborígenes de América del Sur (1901) by Henri Girgois, itself strongly influenced by López's aforementioned study, which has hardly been approached from a critical perspective. Besides, the article purports to contrast both essays with José Imbelloni's, who refutes this kind of speculations, defending in contrast the validity of scientific anthropology. Ultimately, the present work aims at throwing light into the esoteric assumptions of Argentine Indianism later continued by important authors such as Ricardo Rojas during the twenties and thirties.

Este trabajo explora la gravitación imaginaria de Oriente y de la Antigüedad en algunas visiones sobre el mundo andino, producidas entre fines del siglo XIX y e inicios del siglo XX. Analiza las comparaciones que establecen algunos intelectuales entre el legado indígena y el pasado "indoeuropeo", con la legitimación de las periferias que se inicia entre los indianistas románticos, crece en algunos sectores vinculados al espiritualismo en entresiglos, y se expande a partir de la crisis desatada por la Primera Guerra Mundial. 
En Argentina, autores como Vicente Fidel López y Henri Girgois subrayan los lazos entre el mundo andino y Oriente, en base a remotos contactos culturales y a formas semejantes de conceptualizar el mundo. Partiendo de Les races aryennes du Pérou (1871) de Vicente Fidel López, este artículo considera especialmente el ensayo El oculto entre los aborígenes de América del Sur (1901) de Henri Girgois, fuertemente influido por el texto previo de López, y muy poco considerado hasta el presente por la crítica.

Asimismo, busca contrastar estas perspectivas con la refutación de José Imbelloni, que reacciona contra ese tipo de especulaciones, para consolidar por oposición la validez de la antropología científica.

En última instancia, el trabajo busca iluminar las bases esotéricas del indianismo argentino posterior, de autores importantes en los años veinte y treinta como Ricardo Rojas.

INDEX

Keywords: Indianism, Esoterism, Latinamerica, Vicente Fidel López, Henri Girgois

Palabras claves: Indianismo, esoterismo, América Latina, Vicente Fidel López, Henri Girgois

\section{AUTHOR}

\section{ALEJANDRA MAILHE}

Universidad Nacional de La Plata,

Consejo Nacional de Investigaciones Científicas y Técnicas, Argentina

Correo electrónico: amailhe@fahce.unlp.edu.ar 